\title{
CLINICAL, ENDOSCOPIC AND MANOMETRIC FEATURES OF THE PRIMARY MOTOR DISORDERS OF THE ESOPHAGUS
}

\author{
Aspectos clínicos, manométricos e endoscópicos dos distúrbios motores primários do esôfago \\ Júlio César MARTINEZ, Gustavo Rosa de Almeida LIMA, Diego Henrique SILVA, Alexandre Ferreira DUARTE, \\ Neil Ferreira NOVO, Ernesto Carlos da SILVA, Pérsio Campos Correia PINTO, Alexandre Moreira MAIA
}

From the Faculdade de Ciências Médicas, Pontifícia Universidade Católica de São Paulo (Medical Sciences Faculty, Catholic University of São Paulo), São Paulo, SP, Brazil

HEADINGS - Esophageal motility disorders. Endoscopy. Manometry.
ABSTRACT - Background: Significant incidence, diagnostic difficulties, clinical relevance and therapeutic efficacy associated with the small number of publications on the primary esophageal motor disorders, motivated the present study. Aim: To determine the manometric prevalence of these disorders and correlate them to the endoscopic and clinical findings. Methods: A retrospective study of 2614 patients, being 1529 (58.49\%) women and 1085 (41.51\%) men. From 299 manometric examinations diagnosed with primary esophageal motor disorder, were sought-clinical data (heartburn, regurgitation, dysphagia, odynophagia, non-cardiac chest pain, pharyngeal globe and extra-esophageal symptoms) and/or endoscopic (hiatal hernia, erosive esophagitis, food waste) that motivated the performance of manometry. Results: Were found 49 cases of achalasia, 73 diffuse spasm, 89 nutcracker esophagus, 82 ineffective esophageal motility, and six lower esophageal sphincter hypertension. In relation to the correlations, it was observed that in 119 patients clinical conditions were associated with dysphagia, found in achalasia more than in other conditions; in relationship between endoscopic findings and clinical conditions there was no statistical significance between data. Conclusion: The clinical and endoscopic findings have little value in the characterization of the primary motor disorders of the esophagus, showing even more the need for manometry, particularly in the preoperative period of gastroesophageal reflux disease.

\section{Correspondence:}

Gustavo Rosa de Almeida Lima

grdlima@uol.com.br

Financial source: none

Conflicts of interest: none

Received for publication: 24/07/2014 Accepted for publication: $11 / 11 / 2014$

DESCRTORES - Transtornos da motilidade esofágica. Endoscopia. Manometria.
RESUMO - Racional: A incidência significante, a dificuldade diagnóstica, a relevância clínica e a eficácia terapêutica associada ao pequeno número de publicações sobre os distúrbios motores primários do esôfago, motivou a realização do presente estudo. Objetivo: Verificar a prevalência desses distúrbios em manometrias e relacioná-las aos achados endoscópicos e clínicos. Métodos: Estudo retrospectivo de 2614 pacientes sendo 1529 (58,49\%) do gênero feminino e 1085 (41,51\%) do masculino. A partir de 299 exames manométricos com diagnóstico de distúrbio motor esofagiano primário, procuraram-se os dados clínicos (pirose, regurgitação, disfagia, odinofagia, dor torácica não cardíaca, globo faríngeo e sintomas extra-esofageanos) e/ou endoscópicos (hérnia de hiato, esofagite erosiva, resíduos alimentares) que motivaram a realização da manometria. Resultados: Foram encontrados 49 casos de acalásia, 73 de espasmo difuso, 89 de esôfago em quebra-nozes, 82 de motilidade esofagiana ineficaz, e seis de esfíncter esofagiano inferior hipertensivo. Em relação às correlações, observou-se em 119 pacientes analisados que, na clínica associada às afecções, a disfagia foi mais encontrada na acalásia do que nas outras afecções; na relação entre os achados endoscópicos e as afecções não houve relevância estatística entre os dados. Conclusão: Os achados clínicos e endoscópicos têm pequeno valor na caracterização das doenças motoras primárias do esôfago, evidenciando ainda mais a necessidade da manometria, particularmente no pré-operatório da doença do refluxo gastroesofágico.

\section{INTRODUCTION}

T he esophageal motility disorders include any condition whose symptoms are mainly dysphagia and chest pain and, thus, suspected of esophageal origin ${ }^{19}$. They may be as uncomfortable feeling of "ball" in the throat (pharyngeal globe), or it can be more noticeable in swallowing. It is common symptom reported by up to $46 \%$ of apparently healthy individuals and with peak incidence in middle age ${ }^{5}$. Dysphagia is common symptom with different forms of presentation, but always with difficulty in swallowing for solids, pastes and/or liquids. Depending on the severity and frequency, may lead patients to weight loss and malnutrition $n^{4,7,13}$.

The prevalence of functional pain, presumably of esophageal origin, is not known. However, pain in non-cardiac chest affects up to $26 \%$ of the general population and has no gender predilection ${ }^{11}$. The gastroesophageal reflux disease is the most common cause for non-cardiac pain, representing up to $60 \%$ of patients. Thus, exclude cardiac chest pain not related to gastroesophageal reflux should be the first 
goal of any diagnostic evaluation ${ }^{3,6}$

Functional diseases of the esophagus are motility disorders that can be primary, if the motor alteration is the very expression of the disease, or secondary, if the underlying disease is systemic and esophageal involvement is only one of its manifestations. Examples of secondary are: diabetes mellitus, chronic idiopathic pseudo-obstruction, scleroderma, mixed connective tissue disease, rheumatoid arthritis, systemic lupus erythematosus, Chagas disease, alcoholism, amyloidosis, myxedema and multiple sclerosis ${ }^{13}$. As the pathophysiological processes in the secondary motor disorders are relatively well defined, it is easy to understand the origin of the abnormality affecting motor function ${ }^{13}$. However, in the absence of obvious cause, the classification of the main motor disorders is based on the lower esophageal sphincter and esophageal peristalsis abnormalities, and recorded by manometry.

Such disorders are currently more understood and can be explained on the basis of inhibitory defect or defective excitatory innervation of esophageal body and lower sphincter. Included in this group are achalasia, diffuse esophageal spasm, nutcracker esophagus, lower esophagea sphincter hypertension, ineffective esophageal motility and lower esophageal sphincter hypotension?.

The objective of this study is to determine the prevalence of primary esophageal motor disorders and relate them to the endoscopic and clinical findings in order to better be characterized.

\section{METHODS}

Were analyzed retrospectively 2614 manometric exams, being 1529 (58.49\%) in women and 1085 (41.51\%) in men, realized in private gastroenterology service, in which primary motor disorders of the esophagus were searched. Were found 299 cases in which were sought clinical and/or endoscopic data that motivated the exams.

Regarding manometry, were evaluated the lower esophageal sphincter (LES), the average respiratory pressure and maximal expiratory pressure evaluated by four radial channels, plus LES relaxation percentage. In the esophageal body was evaluated the presence of peristalsis, the wave conducted percentile (peristaltic) as well as amplitude and duration of the waves. There was also assessment of the upper esophageal sphincter pressure as the average of the four radial channels, in addition to relaxation and synchrony with the pharyngeal contraction.

For the diagnosis of primary esophageal motor disorder the following definitions were followed: 1 ) achalasia - absence of esophageal peristalsis 7,12 ; 2) Nutcracker esophagus - Richter and Gothenburg criteria - characterized, respectively, by the presence of peristaltic contractions of greater amplitude or equal to $180 \mathrm{mmHg}$ measured from the mean amplitude of $3 \mathrm{~cm}$ and $8 \mathrm{~cm}$ above LES $^{16}$ and amplitude of contraction of the esophageal body greater than 180 $\mathrm{mmHg}$ at any level ${ }^{16} ; 3$ ) ineffective esophageal motility - 30\% or more of water swallowing with distal amplitudes below $30 \mathrm{mmHg}^{8}$; 4) diffuse spasm - simultaneous contraction of the distal esophagus in over $20 \%$ of the water swallowing, amplitude of contractions higher than $30 \mathrm{mmHg}$, and normal intermittent peristalsis ${ }^{22}$; 5) hypertensive lower esophageal sphincter - LES pressure more than $45 \mathrm{mmHg}$ with normal LES peristalsis and relaxation ${ }^{8}$.

From the analysis of these data were selected the ones with diagnosis of primary motor disorders of the esophagus. Using the same chart, data were correlated from 119 patients, the endoscopy and clinical manifestations usually associated with primary motor disorders of the esophagus, ie, heartburn, chest pain of presumed esophageal origin dysphagia, odynophagia, regurgitation, pharyngeal globe and extra-esophageal symptoms, particularly cough and hoarseness. Endoscopic evaluation looked for food residue in the esophagus, hiatal hernia and erosive esophagitis.

For statistical analysis, the chi-square test $\left(\chi^{2}\right)$ or Fisher's exact test $(p)^{21}$ were applied, in order to compare prevalence between genders as well as to compare the motor disorders on manometry in relation to symptoms and endoscopic findings. The significance level was set at 0.05 or $5.0 \%$.

\section{RESULTS}

\section{Primary functional disorders}

Were found, according to the esophageal manometry, 49 cases of achalasia; 73 of diffuse spasm; 82 of ineffective esophageal motility; 89 of the esophagus Nutcracker, 21 by the criterion of Richter and 68 by Gothenburg's; and six lower esophageal sphincter hypertension.

In addition, from esophageal manometry with primary motor disorder, only 119 had medical records with clinical and endoscopic examinations subject to analysis, thus the remainder of the examination was not considered in the statistical study.

In achalasia, esophageal Nutcracker both criteria, and ineffective esophageal motility, the percentages were similar for both genders; but, in diffuse spasm and LES hypertension was predominance of women (Figure 1).

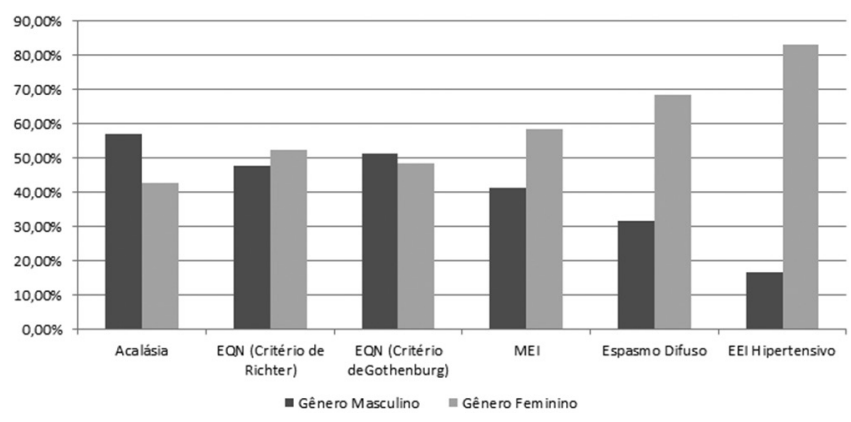

FIGURE 1 - Gender versus primary esophageal disorders

Achalasia $(n=14)$

Associated clinical findings

Heartburn was found in eight patients (57.14\%); insufficiency in nine (64.29\%); dysphagia in nine (64.29\%); non-cardiac chest pain in six (41.86\%); extra-esophageal symptoms (cough and hoarseness) in two (14.29\%). The pharyngeal globe complaints and sore throat were not identified in any of the analyzed patients with manometric diagnosis of achalasia.

\section{Endoscopic findings}

It was verified the presence of hiatal hernia in eight patients (57.14\%); erosive esophagitis in four (28.57\%); and only one $(7.14 \%)$ had residual food at the esophageal lumen.

Diffuse spasm $(\mathrm{n}=33)$

Associated clinical findings

Heartburn was reported in 24 patients $(72.72 \%)$; regurgitation in 21 (63.63\%); dysphagia in 12 (36.36\%); non-cardiac chest pain in eight $(24.24 \%)$; two pharyngeal globe (6.06\%); three odynophagia (9.09\%); extra-esophageal symptoms (cough and hoarseness) in five (15.15\%).

\section{Endoscopic findings}

The presence of hiatal hernia was described in 22 patients (66.66\%); and erosive esophagitis in 13 (39.39\%). Was not found any food waste on these patients.

Ineffective esophageal motility $(n=29)$ 


\section{Associated clinical findings}

Heartburn was present in 21 patients (72.41\%); regurgitation in 21 (72.41\%); dysphagia in four (13.79\%); noncardiac chest pain in four (13.79\%); pharyngeal globe in six (20.69\%); one odynophagia (3.45\%); and extra-esophageal symptoms (cough and hoarseness) in 13 patients (44.83\%).

\section{Endoscopic findings}

Hiatal hernia was present in 18 patients (63.07\%); erosive esophagitis in 17 (58.62\%); and food waste in one patient (3.45\%).

\section{Nutcracker esophagus $(n=40)$}

According to the Richter criterion $(n=17)$

Associated clinical findings

Heartburn was found in 13 patients (76.47); regurgitation in six (35.29\%); dysphagia in four (23.53\%); non-cardiac chest pain in four (23.53\%); two pharyngeal globe (11.76\%); and extra-esophageal symptoms (cough and hoarseness) in three (17.65\%). Odynophagia was not found in any patient.

Endoscopic findings

Erosive esophagitis was found in nine patients (52.94\%); and hiatal hernia in 13 (76.47\%). In none was confirmed the presence of food waste on exam.

According to the Gothenburg criterion $(n=23)$

Associated clinical findings

Heartburn was found in 20 patients $(86.96 \%)$; regurgitation in 10 (43.48\%); dysphagia in seven (30.43\%); non-cardiac chest pain in six (26.09\%); pharyngeal globe in five (21.74\%); two odynophagia (8.70\%); and extra-esophageal symptoms (cough and hoarseness) in 11 (47.83\%).

Endoscopic findings
Was found hiatal hernia in 20 patients (86.96\%); and erosive esophagitis in seven (30.43\%). No patient showed the presence of food waste through endoscopy.

Lower esophageal sphincter hypertension $(n=3)$

Associated clinical findings

Heartburn was found in two patients (66.66\%); regurgitation in one (33.33\%); dysphagia in one (33.33\%); non-cardiac chest pain in one (33.33\%); pharyngeal globe in one (33.33\%); sore throat in one (33.33\%); and extra-esophageal symptoms (cough and hoarseness) in two.

\section{Endoscopic findings}

The presence of hiatal hernia was found in two patients (66.66\%); erosive esophagitis and in one (33.33\%). There was no residual food with endoscopy.

Table 1 summarizes the clinical and endoscopic data analyzed findings.

\section{Associated clinical disorders and diseases $(n=119)$}

Dysphagia versus disorders

Dysphagia was more frequently found in achalasia than in other conditions (Figure 2).

Extra-esophageal symptoms versus diseases

Hypertensive LES was the disosrder with more extraesophageal symptoms (Figure 3)

\section{Endoscopic findings and diseases}

There was no statistical relevance of these data.

TABLE 1 - Incidence of clinical and endoscopic findings correlated to manometric data $(n=119)$

\begin{tabular}{|c|c|c|c|c|c|c|c|}
\hline & & \multirow{2}{*}{$\begin{array}{l}\text { Achalasia } \\
(n=14)\end{array}$} & \multirow{2}{*}{$\begin{array}{l}\text { Diffuse } \\
\text { esophageal } \\
\text { spasm } \\
(n=33)\end{array}$} & \multirow{2}{*}{$\begin{array}{c}\text { Ineffective } \\
\text { esophageal motility } \\
(n=29)\end{array}$} & \multicolumn{2}{|c|}{$\begin{array}{l}\text { Nutcracker esophagus } \\
\qquad(n=40)\end{array}$} & \multirow{2}{*}{$\begin{array}{l}\text { Lower esophageal } \\
\text { sphincter } \\
\text { hypertension } \\
(n=3)\end{array}$} \\
\hline & & & & & Richter $(n=17)$ & Gothenburg $(n=23)$ & \\
\hline \multirow{7}{*}{$\begin{array}{l}\text { Associated } \\
\text { clinical } \\
\text { findings }\end{array}$} & Pyrosis & $8(57,14 \%)$ & $24(72,72 \%)$ & $21(72,41 \%)$ & $13(76,47 \%)$ & $20(86,96 \%)$ & $2(66,66 \%)$ \\
\hline & Regurgitation & $9(64,29 \%)$ & $21(63,63 \%)$ & $21(72,41 \%$ & $6(35,29 \%)$ & $10(43,48 \%)$ & $1(33,33 \%)$ \\
\hline & Disphagia & $9(64,29 \%)$ & $12(36,36 \%)$ & $4(13,79 \%)$ & $4(23,53 \%)$ & $7(30,43 \%)$ & $1(33,33 \%)$ \\
\hline & $\begin{array}{l}\text { Non-cardiac chest } \\
\text { pain }\end{array}$ & $6(41,86 \%)$ & $8(24,24 \%)$ & $4(13,79 \%)$ & $4(23,53 \%)$ & $6(26,09 \%)$ & $1(33,33 \%)$ \\
\hline & $\begin{array}{l}\text { Extra-esophageal } \\
\text { symptoms }\end{array}$ & $2(14,29 \%)$ & $5(15,15 \%)$ & $13(44,83 \%)$ & $3(17,65 \%)$ & $11(47,83 \%)$ & $2(66,66 \%)$ \\
\hline & Pharingeal globe & - & $2(6,06 \%)$ & $6(20,69 \%)$ & $2(11,76 \%)$ & $5(21,74 \%)$ & $1(33,33 \%)$ \\
\hline & Odinophagia & - & $3(9,09 \%)$ & $1(3,45 \%)$ & - & $2(8,70 \%)$ & $1(33,33 \%)$ \\
\hline \multirow{3}{*}{$\begin{array}{l}\text { Endoscopic } \\
\text { findings }\end{array}$} & Hiatal hernia & $8(57,14 \%)$ & $22(66,66 \%)$ & $18(63,07 \%)$ & $9(52,94 \%)$ & $20(86,96 \%)$ & $2(66,66 \%)$ \\
\hline & Erosive esophagitis & $4(28,57 \%)$ & $13(39,39 \%)$ & $17(58,62 \%)$ & $13(76,47 \%)$ & $7(30,43 \%)$ & $1(33,33 \%)$ \\
\hline & $\begin{array}{l}\text { Residual waste in } \\
\text { esophageal lumen }\end{array}$ & $1(7,14 \%)$ & - & $1(3,45 \%)$ & - & - & - \\
\hline
\end{tabular}

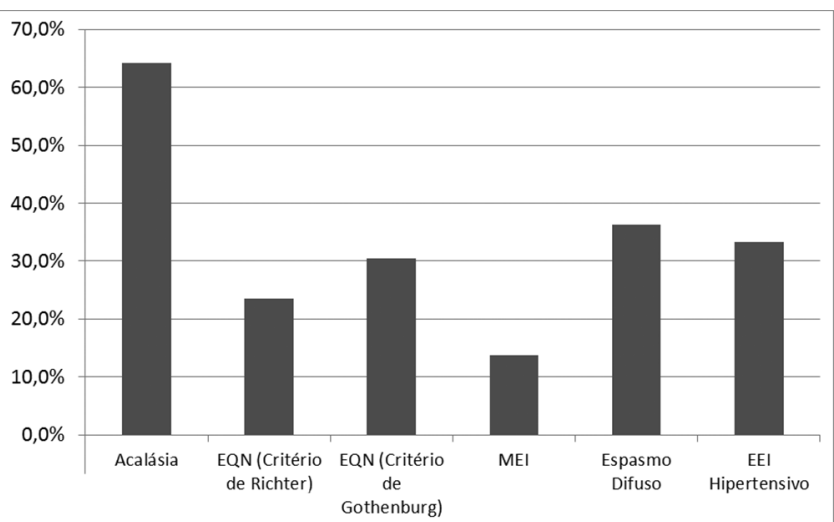

FIGURE 2 - Dysphagia distribution between esophageal primary motor disorders

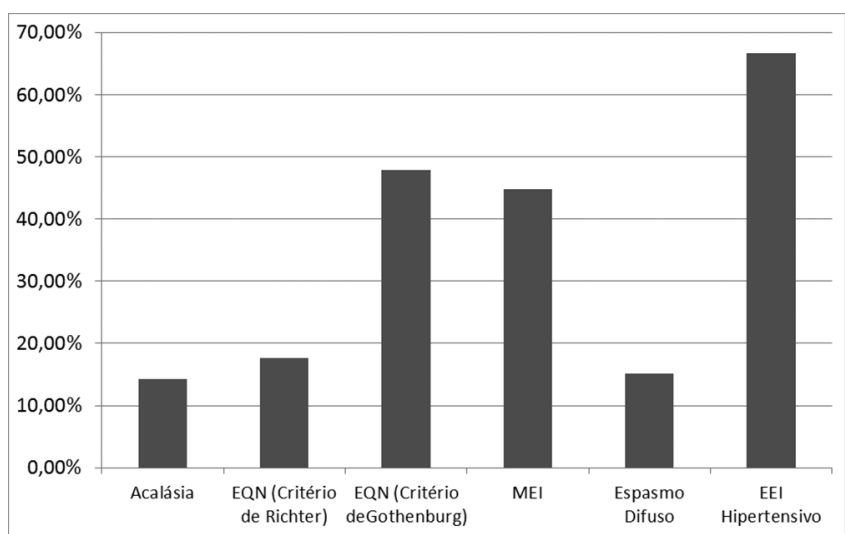

FIGURE 3 - Distribution of extra-esophageal symptoms of primary esophageal motor diseases 
Esophageal manometry is considered the gold standard test for diagnosis of functional disorders of the esophagus. It is possible to identify the presence or absence of esophageal aperistalsis, no relaxation or incomplete LES relaxation, in the case of achalasia ${ }^{17}$.

Based on the results observed in this study it is clear that it cannot be taken into consideration only the heartburn and erosive esophagitis in the diagnosis of gastroesophageal reflux disease as criteria for performing surgical treatment, since there are also significant prevalence of this symptom and endoscopic finding in other primary functional disorders of the esophagus, so, demonstrating the need of manometry as a preoperative examination in patients with this condition.

Many studies report dysphagia and regurgitation as main symptoms of achalasia ${ }^{1,8,15}$ with prevalence rates above $90 \%$ and $76-91 \%$, respectivamente ${ }^{1,14}$. In this paper dysphagia was observed in only $64.29 \%$ of patients; even more common than in other primary motor disorders of the esophagus, it cannot be considered pathognomonic. Stand out from here the importance of dysphagia scales that could better characterize and allow proper comparison with the literature ${ }^{20}$. Its clinical importance lies in the fact that it is the main symptom of the primary functional diseases of the esophagus and its characterization is essential to the management of these patients ${ }^{2}$.

The cough and hoarseness symptoms were observed in all primary esophageal disorders, but more prevalent in hypertensive lower esophageal sphincter, although with the bias of the small sample in this condition.

The cases of Nutcracker esophagusl diagnosed by either Richter or Gothenburg criteria did not change significantly among the analyzed parameters.

Note that these data were obtained with conventional manometry and currently there is high-resolution manometry, which was developed with lumen catheters spaced less than $2 \mathrm{~cm}$. This examination reveals the complex functional anatomy of esophageal peristalsis and esophagogastric junction $9,10,18$. It improves the ability to verify the effectiveness to conduct the bolus through the esophagus and the occurrence of reflux, compared to the conventional system ${ }^{9,10,18}$. Although in general the diagnostic correlation between the two is high, the new method improves the diagnostic yield, especially in cases of functional dysphagia.

The measurement of the esophagogastric pressure gradient increases diagnostic accuracy for achalasia in the differential diagnosis with diffuse spasm. It differs from the rapid rise in intra-bolus pressure (focal dysmotility or impaired function of the LES), which occurs in achalasia ${ }^{9,10,18}$.

Thus, the correlation between manometric findings and the future of the treatment of achalasia needs to be revised in the near future, including chagasic etiology ${ }^{23}$.

So, with this more accurate methodology it could be verified that in this study the cases of achalasia were underestimated, possibly requiring change on strategy, as that preferential treatment is surgical and effective.
The clinical and endoscopic findings have little value in the characterization of the primary motor disorders of the esophagus, showing even more the need for manometry, particularly in the preoperative period of gastroesophageal reflux disease.

\section{REFERENCES}

1. Boeckxstaens GE, Zaninotto G, Richter JE. Achalasia. Lancet 2014 Jan; 383(9911):83-93.

2. Cuenca RM, Malafaia DT, Souza GM, Souza LRQ Motta VP, Lima MRA, Garcia CJFS. Síndrome Disfágica. ABCD Arq Bras Cir Dig 2007; 20(2):116-8.

3. Dekel R, Fass R. Current Perspectives on the Diagnosis and Treatment of Functional Esophageal Disorders. Current gastroenterology reports 2003; 5(4):314-22.

4. Domingues $G R$, Lemme EMO. Diagnóstico diferencial dos distúrbios motores esofagianos pelas características da disfagia. Arq Gastroenterol 2001; 38(1):14-8.

5. Drossman DA, Li Z, Andruzzi E, Temple RD, Talley NJ, Thompson WG, et al. U.S. householders survey of functional gastrointestinal disorders. Prevalence, sociodemography, and health impact. Dig Dis Sic 1993; 38(9):1569-80.

6. Drossman DA. The Functional Gastrointestinal Disorders and the Rome III Process. Gastroenterology 2006; 130(5):1377-90.

7. Eckardt AJ, Eckardt VF. Current clinical approach to achalasia. World J Gastroenterol 2009 Aug; 15(32):3969-75.

8. Fisichella PM, Carter SR, Robles LY. Presentation, diagnosis, and treatment of oesophageal motility disorders. Dig Liver Dis 2012, 44(1):1-7.

9. Fisichella PM, Jalilvand A, Lebenthal A.: Diagnostic Evaluation of Achalasia: From the Whalebone to the Chicago Classification. World J Surg. 2015 Jan 10. [Epub ahead of print]

10. Fox MR, Bredenoord AJ; Oesophageal high-resolution manometry: moving from research into clinical practice. Gut 2008; 57(3):405-23.

11. Locke GR 3rd, Talley NJ, Fett SL, Zinsmeister AR, Melton LJ 3rd. Prevalence and clinical spectrum of gastroesophageal reflux: a population-based study in Olmsted County, Minnesota. Gastroenterology 1997 May; 112(5):1448-56.

12. Mikaeli J, Farrokhi F, Bishehsari F, Mahdavinia M, Malekzadeh R. Gender effect on clinical features of achalasia: a prospective study. BMC Gastroenterol 2006; 6(12).

13. Mittal RK, Bhalla V. Oesophageal Motor Functions and its Disorders. Gut 2004; 53(10):1536-42.

14. Moonen AJ, Boeckxstaens GE. Management of Achalasia. Gastroenterol Clin N AM 2013 March; 42(1):45-55.

15. Pandolfino JE, Kahrilas PJ. Presentation, Diagnosis, and Management of Achalasia. Clin Gastroenterol Hepatol 2013 Aug; 11(8):887-97.

16. Pilhall M, Börjesson M, Rolny P, Mannheimer C. Diagnosis of NutcrackerEsophagus, Segmental or Diffuse Hypertensive Patterns, and Clinical Characteristics. Dig Dis Sci 2002 June; 47(6):1381-8.

17. Pohl D, Tutuian R. Achalasia: an Overview of Diagnosis and Treatment. J Gastrointestin Liver Dis 2007; 16(3):297-303.

18. Richter JE. High-resolution manometry in diagnosis and treatment of achalasia: help or hype. Curr Gastroenterol Rep. 2014 Dec;16(12):420

19. Ritcher JE. Oesophageal motility disorders. Lancet 2001 Set; 358(9284):823-8.

20. Sallum RAA, Duarte AF, Cecconello I. Analitic review of disphagia scales. ABCD Arq Bras Cir Dig 2012; 25(4):279-32.

21. Siegel S, Castellan NJJ. Estatística não paramétrica para ciências do comportamento. 2. ed. Porto Alegre: Penso;2006. p. 448.

22. Tsuboi K, Mittal SK. Diffuse esophageal spasm: has the term lost its relevance? Analysis of 217 cases. Dis Esophagus 2011; 24:354-9.

23. Vicentine FP, Herbella FA, Allaix ME, Silva LC, Patti MG. High-resolution manometry classifications for idiopathic achalasia in patients with Chagas' disease esophagopathy. J Gastrointest Surg. 2014 Feb;18(2):221-4. 